\title{
CONSERVATION STATUS OF LOMATIUM ATTENUATUM EVERT (APIACEAE) IN MONTANA
}

\author{
Prepared by: \\ Jim Vanderhorst and Bonnie L. Heidel \\ Montana Natural Heritage Program \\ State Library \\ 1515 East Sixth Avenue \\ Helena, Montana 59620-1800 \\ Prepared for: \\ United States Department of Interior \\ Bureau of Land Management \\ P.O. Box 36800 \\ Billings, Montana 59107-6800
}

Agreement No. 1422E930A960015, Task Order No. 5

January, 1998 


\section{1998 Montana Natural Heritage Program}

This document should be cited as follows:

Vanderhorst, J. and B. L. Heidel. 1998. Conservation status of Lomatium attenuatum Evert in Montana. Unpublished report to the Bureau of Land Management. Montana Natural Heritage Program, Helena. 20 pp. + app. 


\section{SUMMARY}

There are nine occurrences of Lomatium attenuatum (Taper-tip Desert-parsley) known in Montana. These are from Beaverhead and Madison counties with three geographic centers in the Grasshopper Creek drainage, the Ruby Range, and the Tendoy Range. Most populations are on lands administered by the Bureau of Land Management, followed by Beaverhead National Forest and Montana state lands. Total population numbers in Montana are estimated between 10,000 and 100,000 plants, comparable with total numbers found in Wyoming, the only other place where this species occurs. Populations face few direct threats, but invasions of exotic weeds and mining may potentially threaten the species in the future. Due to relatively high population numbers, wide ecological amplitude, and low degree of threats, current BLM Sensitive status is recommended changed to Watch status. 


\section{ACKNOWLEDGEMENTS}

This project was made possible by a challenge cost-share agreement between the Bureau of Land Management and the Montana Natural Heritage Program. Special thanks are extended Brian Hockett (Bureau of Land Management) who provided coordination and access information, Cathy Seibert (Montana State University) who provided Saturday access to the herbarium (MONT) and graciously provided accommodations and hospitality, Walter Fertig (Wyoming Natural Diversity Database) who provided up-to-date information on Wyoming populations of Lomatium attenuatum, Dr. Ronald Hartman (University of Wyoming) who compared Montana and Wyoming specimens of the species and verified determinations of nearly all Montana collections of Lomatium attenuatum, John Hinshaw and Cedron Jones (Montana Natural Heritage Program) who produced the GIS maps, and Anne Dalton (Montana Natural Heritage Program) who processed element occurrence data in the Biological Conservation Database. 


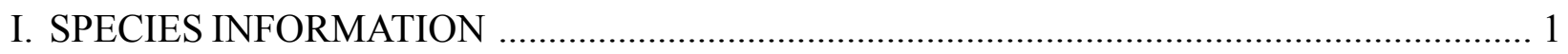

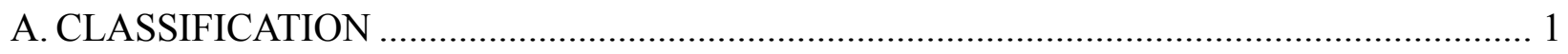

B. PRESENT LEGAL OR OTHER FORMAL STATUS ......................................................... 1

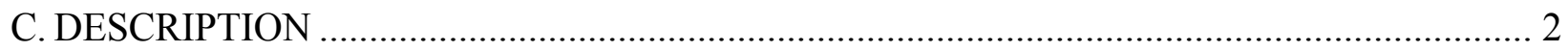

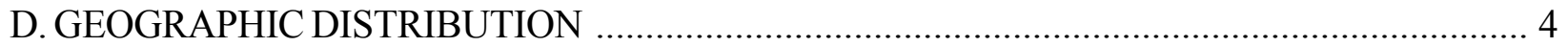

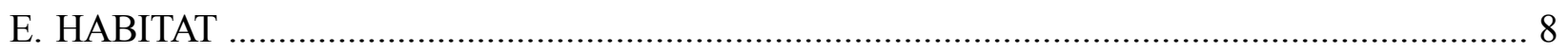

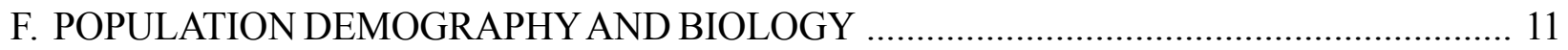

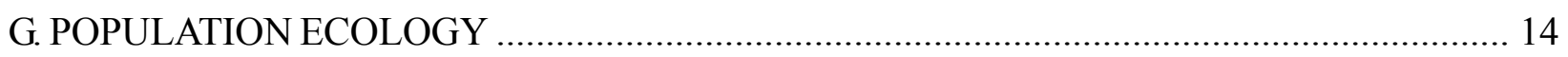

II. ASSESSMENT AND MANAGEMENT RECOMMENDATIONS ……………................... 15

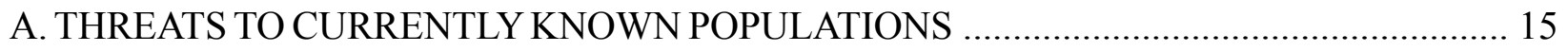

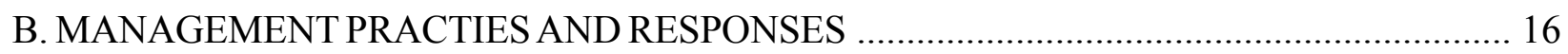

C. RECOMMENDATIONS FOR MAINTAINING VIABLE POPULATIONS ........................... 16

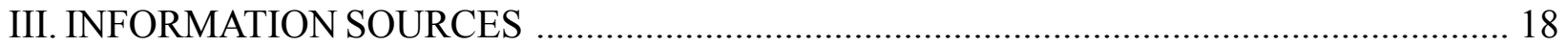

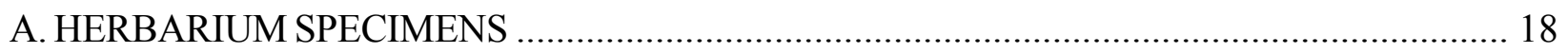

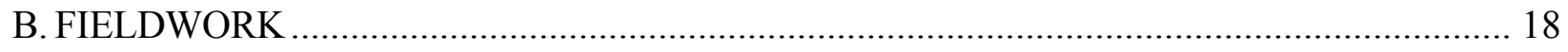

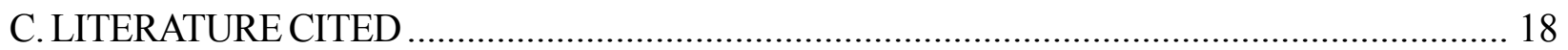

LIST OF FIGURES AND TABLE

FIGURE 1. LINE DRAWING OF LOMATIUM ATTENUATUM ……........................................ 3

FIGURE 2. MONTANA OCCURRENCES OF LOMATIUM ATTENUATUM ............................... 6

FIGURE 3. BANNACK AREA POPULATIONS OF LOMATIUM ATTENUATUM ................... 13

TABLE 1. MONTANA OCCURRENCES OF LOMATIUM ATTENUATUM ………….................. 5

APPENDIX A. ELEMENT OCCURRENCE RECORDS FOR LOMATIUMATTENUATUM (not included in online version) 
I. SPECIES INFORMATION

\section{A. CLASSIFICATION}

1. SCIENTIFIC NAME: Lomatium attenuatum Evert

2. SYNONYMS: None

3. COMMON NAME: Taper-tip Biscuitroot, referring to the long, tapering involucel bracts. In Wyoming it is commonly called Absaroka biscuitroot (Fertig 1997).

4. BIBLIOGRAPHIC CITATION: Lomatium attenuatum was first described based on specimens collected from the Absaroka Mountains in Wyoming; Evert, E. 1983. MadroÒo 30(3): 143-146.

5. TYPE SPECIMEN: United States, Wyoming, Park County, Absaroka Range, E. F. Evert 1756 (Holotype RM; isotypes: MO, NY, UC, MOR).

6. FAMILY: Apiaceae, also known by its conserved name, the Umbelliferae; the carrot or parsley family.

7. GENUS: Lomatium is a genus of 70-80 species of perennial herbs of western North America (Constance 1993), nearly half of which are relatively narrow endemics (Soltis et al. 1997).

8. SPECIES: This recently described species has not been published in floras except for Dorn (1992). It was considered a possible variety of the widespread and variable Lomatium cous complex when it was first collected. It resembles L. cous in habit, leaf dissection, and fruit size, shape and texture. However, it consistently differs in its inconspicuous involucel, elongate pedicels, distribution of vittae (band pattern) on the fruit, and overall scabrosity; more closely resembling L. vaginatum and L. canbyi in these other characteristics (Evert 1983). Relationships with other species have not been investigated. it is parapatric though not sympatric with L. cous and does not overlap in distribution with the latter two species.

\section{B. PRESENT LEGAL OR OTHER FORMAL STATUS}

\section{FEDERALSTATUS}

a. U.S. FISH AND WILDLOIFE SERVICE: None. It was formerly listed as Category 3C (USDI Fish and Wildlife Service 1993), removing it from Category 2 (C2) status based on the recommendations in Dorn 
(1989). Listing of C2 species was officially discontinued by the Service in 1996 (USDI Fish and Wildlife Service 1996).

b. BUREAU OF LAND MANAGEMENT: Sensitive(USDI BLM 1996).

\section{STATE STATUS}

a. MONTANA: The Montana Natural Heritage Program ranked Lomatium attenuatum $\mathrm{G} 2 \mathrm{~S} 2$; imperiled by rarity globally and in the state (Heidel 1997). The results of this status review and recent surveys in Wyoming (Fertig 1997) provide the documentation for changing global rank to $\mathrm{G} 3$.

b. WYOMING: The Wyoming Natural Diversity Database ranks Lomatium attenuatum S2 (Fertig 1996; see definition above).

\section{DESCRIPTION}

1. GENERAL NONTECHNICAL DESCRIPTION: Taper-tip Biscuitroot is a low herbaceous perennial growing from an elongated, thickened taproot. It has short stems that bear one or two finely dissected leaves that are $2-11 \mathrm{~cm}$ long and oval-shaped in outline with narrow ultimate segments $<1.5 \mathrm{~mm}$ wide. The herbage, flower stem, and inflorescence are scaberulous (minutely rough to the touch). The inflorescence is a many flowered compound umbel (like an umbrella) borne on a long naked stalk which exceeds the leaves in fruit. The involucre (bracts at the base of main umbel branches) is absent or inconspicuous, and the involucel (bractlets at the base of the secondary umbel branches) is absent or consists of 1-6 narrow, attenuate (long tapering) bracts 1-4 mm long. The umbellets (secondary umbels) have about 15 tiny, yellowpetaled flowers. The mature fruits lack hairs, are flattened with low ribs on the faces and are 5-8 $\mathrm{mm}$ long and 3-5 $\mathrm{mm}$ wide. Figure 1 is a line drawing of Lomatium attenuatum.

2. TECHNICAL DESCRIPTION: Plant perennial, short-caulescent, with only 1 or 2 cauline leaves, more or less scaberulous, (7-)10-25 cm tall, from an elongated thickened taproot, and also occasionally from a several-branched caudex; leaves petiolate, 3-pinnate or ternately 3-pinnate, blades $2.0-11 \mathrm{~cm}$ long, $1.5-10 \mathrm{~cm}$ wide, ovate in outline, the ultimate divisions 


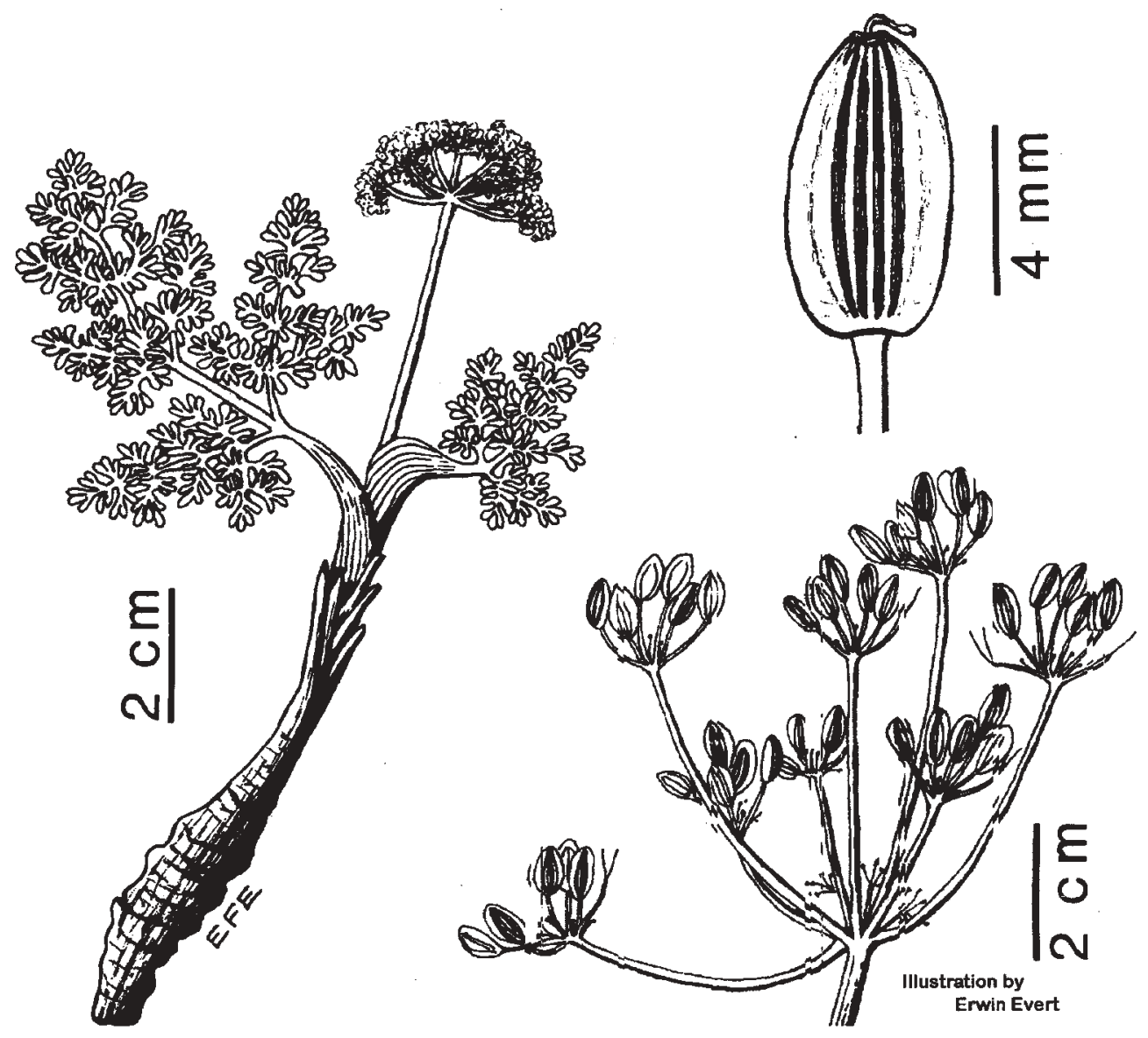

Figure 1. Line drawing of Lomatium attenuatum 
linear to oblanceolate, $2-5 \mathrm{~mm}$ long, $0.5-1.5 \mathrm{~mm}$ wide, obtuse to somewhat acute and mucronate petioles $1.5-5 \mathrm{~cm}$ long, the dilated and scarious sheathing extending to the middle or above; peduncles 1-3(-4), scaberulous, exceeding the leaves in fruit, $10-15 \mathrm{~cm}$ long; involucre usually absent but occasionally 1 inconspicuous, filiform bract present;

fertile rays 5-8, spreading, angled, unequal, (1.5-) $3-5 \mathrm{~cm}$ long in fruit; sterile rays $4-8$, spreading, $3-10 \mathrm{~mm}$ long in fruit; involucel absent or of 1-6 inconspicuous linear-lanceolate, attenuate, nonconnate bractlets, 1-4 mm long; umbellets ca. 15-flowered, only 26 developing into fruit; pedicels $3-10 \mathrm{~mm}$ long in fruit; petals 1.5 $\mathrm{mm}$ long including the incurved apex, yellow, obovate, glabrous; sepals inconspicuous; anthers ca. $0.5 \mathrm{~mm}$ long, yellow; styles 1-1.5 $\mathrm{mm}$ long, spreading or reflexed; ovaries glabrous to slightly scaberulous; fruit oblong-elliptic, glabrous, glossy, 5-8 $\mathrm{mm}$ long, $3-5 \mathrm{~mm}$ wide, the wings ca. $0.5-0.75 \mathrm{~mm}$ wide, narrower than the body; oil tubes prominent, 1 in each interval, 2 on the commissure; carpophore bipartite (from Evert 1983, Marriott 1989).

3. DIAGNOSTIC FIELD CHARACTERS: In habit, leaf dissection, and fruit characters, Lomatium attenuatum resembles the more common and widespread Lomatium cous. However, the former has inconspicuous, attenuated involucel bractlets (hence its specific epithet) while the latter has conspicuous, broadly rounded bractlets. Also, Lomatium attenuatum has greater overall scabrosity. It can be distinguished from low growing species of Cymopterus by its fruits that have low ribs, rather than prominent wings on the flattened sides and celery odor of the crushed leaves (leaves of the cymopterus smell of anise).

\section{GEOGRAPHIC DISTRIBUTION}

1. RANGE: Lomatium attenuatum is a regional endemic of the Rocky Mountains. It is known from 13 occurrences in the Absaroka Mountains in Park Co., Wyoming, restricted to the North Fork Shoshone River drainage where it occurs on the BLM Worland District and the Shoshone National Forest (Fertig 1997). There are three smaller centers in southwestern Montana that are separated from the Wyoming population by over air 100 miles and the Yellowstone highlands.

\section{MONTANADISTRIBUTION}

a. CURRENT SITES: The species was first discovered in the state in 1993 by Peter Lesica on BLM land in the Tendoy Mountains, Beaverhead County (Vanderhorst and Lesica 1994). Additional Beaverhead County populations were found on the Beaverhead National Forest in the Tendoys (Vanderhorst 1995a) and due north in 
the drainage of Grasshopper Creek (Heidel and Vanderhorst 1996, Vanderhorst 1995b). It was found on BLM land in the Ruby Range in 1996 by Bonnie Heidel, the first occurrence documented in Madison County (Vanderhorst et al. 1997). Systematic surveys in the course of this 1997 study located additional places in all three population centers, but no major range extensions were found. There are now a total of nine occurrences known in Montana (Table 1). Figure 2 shows locations of all Montana occurrences. Element Occurrence Records and topographic maps giving precise locations are provided in Appendix A.

b. HISTORICAL SITES: None

c. UNVERIFIED/UNDOCUMENTED REPORTS: None. Determinations of nearly all Montana collections of Lomatium attenuatum have been verified by Dr. Ronald Hartman (Rocky Mountain Herbarium, University of Wyoming), a specialist of the Apiaceae. Every collection of the similar, but more common Lomatium cous at MONT and MONTU were examined by the author, but none were found to be misidentified specimens of Lomatium attenuatum.

TABLE 1. MONTANA OCCURRENCES OF LOMATIUM ATTENUATUM ${ }^{1}$

\begin{tabular}{|l|l|l|}
\hline EO Number and Name & Ownership & $\begin{array}{l}\text { Population number and } \\
\text { area }\end{array}$ \\
\hline 001 Deer Canyon & BLM, Beaverhead NF, MT State & Ca. 2,000, 100+ acres (1997) \\
\hline 002 Limekiln Canyon & BLM & $500-2,000,20+$ acres \\
\hline 003 Bannack & BLM, MT State & $>10,000,160$ acres \\
\hline 004 Sourdough Creek & Beaverhead NF & $1,000-10,000,60$ acres \\
\hline 006 Rocky Hills & BLM & Ca. 60 \\
\hline 007 Road Agents Rock & BLM, private & $500-1,000,40$ acres \\
\hline 008 Cold Spring Creek & BLM, MT State & Ca. $1,500,50+$ acres \\
\hline 009 Laurin Canyon & BLM & $1,000+, 60+$ acres \\
\hline 010 New Departure Mine & BLM & Ca. 200, 10 acres \\
\hline
\end{tabular}

\footnotetext{
${ }^{1}$ There is a gap in the sequence of element occurrence numbers because EO\#005 was merged with EO\#001 and deleted.
} 
Figure 2. Lomatium attenuatum Distribution in Montana

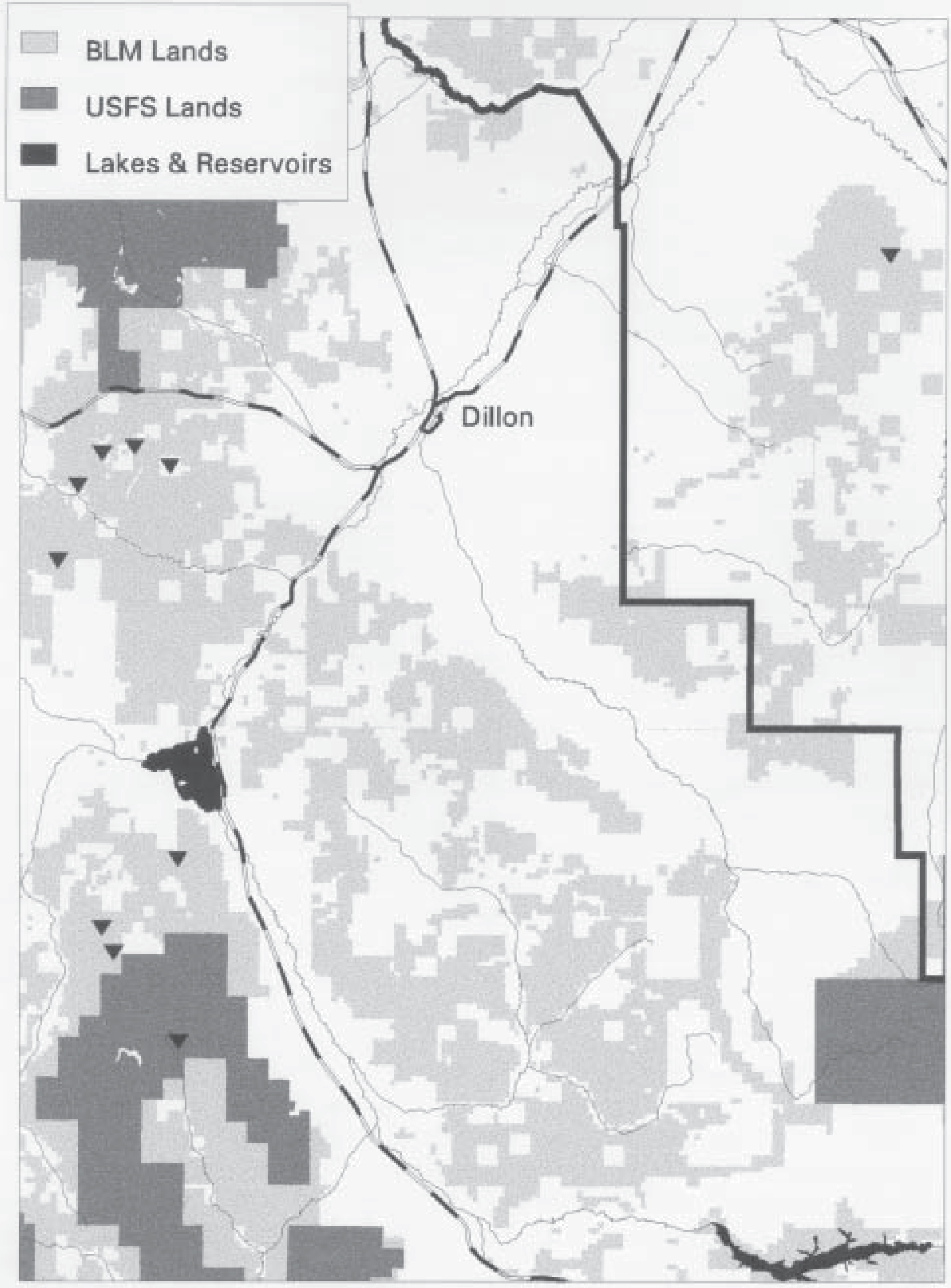

Montana Natural Heritage Program, January 7, 1998 
d. LAND OWNERSHIP: Each of the known Montana occurrences are at least partly on public land: most are on Bureau of Land Management holdings, two populations are partly or entirely on Beaverhead National Forest, two populations are partly on Montana State lands, and one population is partly on private land (Table 1). The population which appears to be largest and most extensive is the Bannack site, primarily on federal lands managed by the Bureau of Land Management. In Wyoming, nearly all populations are on public lands (mostly Shoshone National Forest), and parts of four occurrences are protected within wilderness areas.

AREAS SURVEYED BUT SPECIES NOT FOUND: Status review surveys were conducted for Lomatium attenuatum in 1997, but the species was not found at the following locations:

Henneberry Ridge (south of Grasshopper Creek): Cedar Creek (T9S R11W S14 SE ${ }^{\circ}, \mathrm{S}_{23} \mathrm{NE}^{\circ}$ )

Grasshopper Creek tributary (T9S R11W S12 E $\Omega$, T9S R10W S6 SW ${ }^{\circ}$, $\mathrm{S}_{7} \mathrm{NW}^{\circ}$ )

Hogback (north of Dillon): T5S R8W S16

Lovell Gulch (east of Beaverhead River south of Dillon): (T9S R9W S4 $\mathrm{W} \Omega, \mathrm{S} 5 \mathrm{E} \Omega$ )

South Pioneer Range:

Argenta (T6S R10W S24 S $\Omega$ )

Badger Pass (T7S R11W S11 S $\Omega$ )

Birch Creek (T5S R9W S19 N $\Omega$ )

Black Mountain Road (T6S R11W S21 NE ${ }^{\circ}, \mathrm{S}_{2} 2 \mathrm{NW}^{\circ}$ )

Lime Gulch (T5S R10W S14)

Scudder Creek (T6S R12W S20 N $\Omega$, S21 NE $^{\circ}$ )

In addition to 1997 status review surveys, MTNHP has conducted extensive sensitive plant surveys in recent years on BLM and Beaverhead National Forest lands throughout foothills and montane areas of southwestern Montana. The fact that Lomatium attenuatum was not found in these surveys is taken to mean that it is not present, or that it was not sought at appropriate times of the growing season. Asterisks indicate the latter among the following studies: Big Bend of the Big Hole River

(Heidel and Vanderhorst 1996), Centennial Valley* (Culver 1993), Dutchman Mountain (Vanderhorst 1994a), Horse Prairie Creek drainage (Vanderhorst 1995c), the vicinity of Lemhi Pass (Vanderhorst 1994b), the vicinity of Sage Creek (Lesica and Vanderhorst 1995), and the Tobacco Root Mountains* (Vanderhorst and Heidel 1995), in addition to unoccupied segments of the 
Grasshopper Creek drainage (Heidel and Vanderhorst 1996, Vanderhorst 1995b) and Tendoy Mountains (Vanderhorst 1995a, Vanderhorst and Lesica 1994). Appendices of these reports provide maps of areas searched.

\section{E. HABITAT}

1. ASSOCIATED VEGETATION: Montana habitats of Lomatium attenuatum are typically semi-forested scree, scrubland, woodland, or grassland on shallow soils. They are most often centered in exposed microhabitat openings dominated by sparse cover of bluebunch wheatgrass (Elymus spicatus) and high proportion of exposed gravel. The surrounding settings are commonly dominated by limber pine (Pinus flexilis), Douglas fir (Pseudostuga menziesii), and/or mountain mahogany (Cercocarpus ledifolius). At a few sites Leucopoa kingii replaces Elymus spicatus as the dominant bunchgrass. They are distributed in landscape mosaics in which Lomatium attenuatum populations often extend across plant community boundaries. A subpopulation of the Deer Creek Canyon occurrence is concentrated beneath canopies of large Pinus flexilis. A few populations extend into big sagebrush (Artemisia tridentata ssp. vasyana and $A$. tridentata ssp. tridentata) or low sagebrush (A. nova) communities. Lomatium attenuatum has been documented from the following plant associations and community types (sequenced from most frequent to least frequent):

Elymus spicatus/scree

Cercocarpus ledifolius/Elymus spicatus

Pseudotsuga menziesii/scree

Pinus flexilis/Elymus spicatus

Artemisia tridentata ssp. vaseyana/Elymus spicatus

Pinus flexilis/Festuca idahoensis

Pseudotsuga menziesii/Elymus spicatus

Artemisia tridentata ssp. vaseyana/Festuca idahoensis

Artemisia nova/Elymus spicatus

Artemisia tridentata ssp. tridentata/Elymus smithii

Associated flora, in addition to community dominants, is characterized by many species adapted to arid lithosols, and includes many obligate and facultative calciophiles, including the BLM Sensitive species Lesquerella pulchella and Sphaeromeria argentea and BLM Watch species Phacelia incana. At one site (Cold Spring Creek), habitat overlaps with that of the BLM sensitive species Astragalus scaphoides but this is not typical. Other state and regional calciphilic endemics in the same habitats that are on the state Watch list include: Delphinium bicolor ssp. calcicola, Townsendia nuttallii, and Townsendia spathulata. Infestations of weeds are light, but several exotic species occur in the population areas (marked by an asterisk in the list below). The habitats are likely to be prone to infestations of the noxious weed Centaurea maculosa (spotted knapweed), but the species was not seen in population areas. It is 
just becoming established in southwestern Montana, with small populations observed along travel routes nearby Lomatium attenuatum occurrences in the Ruby and Tendoy ranges. The following vascular plant species were observed at one or more Lomatium attenuatum site in Montana.

Trees: Juniperus scopulorum, Pinus flexilis, Pseudotsuga menziesii

Shrubs: Artemisia frigida, Artemisia tridentata ssp. tridentata, Artemisia tridentata ssp. vaseyana, Cercocarpus ledifolius, Chrysothamnus nauseosus, Chrysothamnus viscidiflorus, Guttierezia sarothrae, Juniperus communis, Mahonia repens, Opuntia polyacantha, Ribes cereum, Rosa woodsii, Tetradymia canescens

Grasses and sedges: Elymus smithii, Elymus spicatus, Carex rossii, Festuca idahoensis, Leucopoa kingii, Oryzopsis hymenoides, Poa cusickii, Poa interior, Poa pratensis*, Poa scabrella

Forbs: Achillea millefolium, Allium cernuum, Allium textile, Antennaria microphylla, Arabis drummondii, Arabis nuttallii, Arabis sparsiflora, Arenaria kingii, Artemisia dracunculus, Artemisia ludoviciana, Astragalus adsurgens, Astragalus miser, Astragalus scaphoides, Castilleja angustifolia, Cirsium subniveum, Comandra umbellata, Cryptantha celosioides, Cymopterus nivalis, Delphinium bicolor ssp. calcicola, Douglasia montana, Draba oligosperma, Erigeron caespitosus, Erigeron compositus, Erigeron tweedyi, Eriogonum mancum, Eriogonum microthecum, Eriogonum ovalifolium, Eriogonum umbellatum, Hackelia floribunda, Hackelia patens, Haplopappus acaulis, Ivesia gordonii, Lappula redowskii, Lesquerella alpina, Lesquerella pulchella, Linum lewisii, Lithospermum incisum, Lithospermum ruderale, Lupinus polyphyllus var. humicola, Malcolmia africana*, Medicago lupulina*, Medicago sativa*, Mertensia oblongifolia, Musineon divaricatum, Oenothera caespitosa, Oxytropis besseyi, Oxytropis sericea, Phacelia hastata, Phacelia incana, Phlox hoodii Phlox longifolia, Phlox pulvinata, Penstemon aridus, Petrophyton caespitosum, Physaria geyeri, Potentilla ovina, Potentilla gracilis, Schoenocrambe linifolia, Senecio canus, Senecio streptanthifolius, Solidago missouriensis, Sphaeromeria argentea, Stephanomeria runcinata, Taraxacum officinale*, Townsendia hookeri, Townsendia nuttallii, Townsendia parryi, Townsendia spathulata, Urtica dioica, Verbascum thapsus*, Viola nuttallii

Vegetation of Wyoming sites with Lomatium attenuatum is similar to those in Montana. Recent surveys identified the following community types in population areas on the Shoshone National Forest (Fertig 1997): 
1) Openings dominated by Elymus spicatus, Leucopoa kingii and Oryzopsis hymenoides in woodlands of Pinus flexilis and Pseudotsuga menziesii,

2) Shrubland community dominated by Artemisia tridentata ssp. vasyana and Artemisia nova, and

3) Successional shrub/grass Artemisia tridentata/Chrysothamnus nauseosus/ Elymus spicatus community.

2. TOPOGRAPHY: Montana populations of Lomatium attenuatum typically occur on dry, unstable, moderate to steep, south-facing slopes of mountains, canyons, and foothills. Their position on the slope varies with substrate conditions. The steepest slopes are in canyons, formed from colluvium of overtowering cliffs. Rock outcrops are at nearly all sites. A few populations (e.g. Bannack) extend onto nearly level ridgetops in shallow gravels perched on bedrock. Some large populations extend onto more mesic exposures (northerly) and positions (canyon bottoms and toeslopes). Elevations of the sites range from 5,700 to 8,700 feet (1,737-2,652 meters).

3. SOIL RELATIONSHIPS: Soils are generally poorly developed lithosols with a high proportion of gravel, commonly referred to as scree. The substrates are dry, loose, easily disturbed, and have high water infiltration rates with little or no surface runoff. Surface horizons may be sandy, but subsurface horizons often have clay or silt accumulations, or the gravels are perched on shallow bedrock, ameliorating the droughty surface conditions. A deep, tough rootstock and short period of active growth allows Lomatium attenuatum to exploit seasonal subsurface moisture, avoid damage from shifting scree, and remain dormant in dry years.

Most Montana populations occur on substrates with limestone parent material but populations in the Grasshopper Creek drainage occur on both limestones and igneous rocks. The Cold Spring Creek occurrence (008) has volcanic parent material. There is also local variation in parent material rock type within large populations (e.g. Cold Spring Creek, Deer Creek). In Wyoming, Lomatium attenuatum also grows in both limestone and volcanic derived substrates (Evert 1983, Fertig 1997), but is most often found on volcanics (W. Fertig, personal communication.).

3. CLIMATE FACTORS: The macroclimate of southwestern Montana is continental and semi-arid. Data from Dillon (U.S. Dept. of Commerce, NOAA 1982) is taken to approximate climatic conditions of the basin environments that are adjacent to uplands supporting Lomatium attenuatum. Normal mean temperatures ranged from 20.2 degrees F in January to 66.4 degrees F in July. Normal mean annual precipitation was 11.5 inches. May and June are the wettest months, corresponding to the period of active growth and flowering of Lomatium attenuatum. 
Local climates vary with elevation, aspect, topographic position, and rain shadow effects. Most sites with Lomatium attenuatum have warm southerly aspects. By mid summer the exposed scree is dry and hot and leaves and stems of Lomatium attenuatum are senescent (withered). Year to year climatic fluctuations undoubtedly affect seed production. In 1997, these was a cool, wet growing season following a winter with plentiful snowpack, flowering stem numbers were high, and seed production per plant appeared to be higher than observed in past years. In dry years, high proportions of the plants may remain in a vegetative (non-flowering) condition in which they may be overlooked and taxonomic verification is not possible.

\section{F. POPULATION DEMOGRAPHYAND BIOLOGY}

1. PHENOLOGY: Lomatium attenuatum is a geophyte, completing its phase of active growth and reproduction early in the season corresponding with months of cool temperatures and peak rainfall, and storing energy reserves below-ground. It generally starts flowering by mid-May at low elevation sites and by June at higher elevation sites. Most low-elevation plants had immature fruits at survey dates in late May and early June and mature fruits in July, 1997. This is considered to be about two weeks late in phenology compared to average growing season conditions. At the Ruby Range, the species was initially discovered on July 3, 1996, representing a more normal year, at which time plants were starting to senesce and retained almost none but aborted fruit.

Like other members of the Parsley Family, it has an indeterminate infloresence (Stebbins 1974). It was noted that different umbels of the same plant are often at very different phenological stages, with flowering activity prolonged and overlapping with fruit production in favorable years and in favorable microhabitats.

Mature fruits readily dry and shed under hot, dry conditions, at which time the aboveground plant senesces. Populations are likely to go undetected by late summer surveys, or for that matter by any survey after June in most years.

2. POPULATION SIZE AND CONDITION: Estimated Montana population numbers of the nine known occurrences range from less than 100 to over 10,000 plants (Table 1). At least 4 populations were estimated to consist of over 1,000 plants, and total numbers in Montana are estimated between 10,000 and 100,000 plants; conservatively estimated at 17,000+. Some populations cover extensive areas, the largest (Bannack, Cold Spring Creek, Deer Canyon) consisting of several subpopulations occupying over 100 acres of scattered habitat spanning multiple.

The extensiveness and complexity of speciesí distribution patterns has been addressed in part by digitizing the precise distribution of subpopulations making up each 
occurrence. The distribution of the four occurrences in the Bannack Area is shown as an example in Figure 3, including two of the extensive element occurrences (Bannack, Cold Spring Creek). Despite the extent of subpopulations and collective populations in the three population centers, its occupied habitat is limited in extent and may span less than 2,000 acres range-wide.

As mentioned previously, it is difficult to estimate population numbers if the plant is in fruit, and it is impractical if the plant is in vegetative (non-flowering) condition. Four populations revisited in 1997 (Cold Spring Creek, Deer Canyon, Laurin Canyon, Sourdough Creek) were found to be larger and more extensive than indicated by previous surveys that were incomplete and/or late. The magnitudes of population size remain undetermined in the Rocky Hills.

The species only recently discovered in Montana but is now known to occur in comparable numbers and a broader distribution than currently known in Wyoming. In Wyoming where the species was first discovered, total number of plants is now estimated to be about 10,000 plants, and distribution is confined a single drainage, the North Fork of the Shoshone River, in the Absaroka Range (Fertig 1997). The total number of plants rangewide is in the range of 10,000 to 100,000 plants.

3. REPRODUCTIVE BIOLOGY: Reproduction is entirely by seed. Like other members of the Parsley Family, Lomatium attenuatum is insect-pollinated (after Buchmann and Nabhan 1996). It has been characterized as having low fecundity, with only 2-6 flowers per umbellet developing into fruit (Evert 1983). Low seed production has been noted in Montana populations in past years, but in 1997 seed production was relatively high judging from numbers of developing fruit observed in early June. Some plants were seen with 7 or more fruits per umbel. The number of plants observed in 1997 was also high, indicating high levels of flowering. In unfavorable years plants survive by remaining in vegetative condition, putting out leaves without flowering stems and forfeiting reproduction for the year.

Flowers of Lomatium attenuatum appear to be protogynous, with styles extending before petals spread and anthers dehisce (R. Hartman, personal communication). Asynchronous development of male and female flower parts (dichogamy) is common in the Apiaceae, and is a means of favoring cross pollination. 
Figure 3. Bannack area populations of Lomatium attenuatum

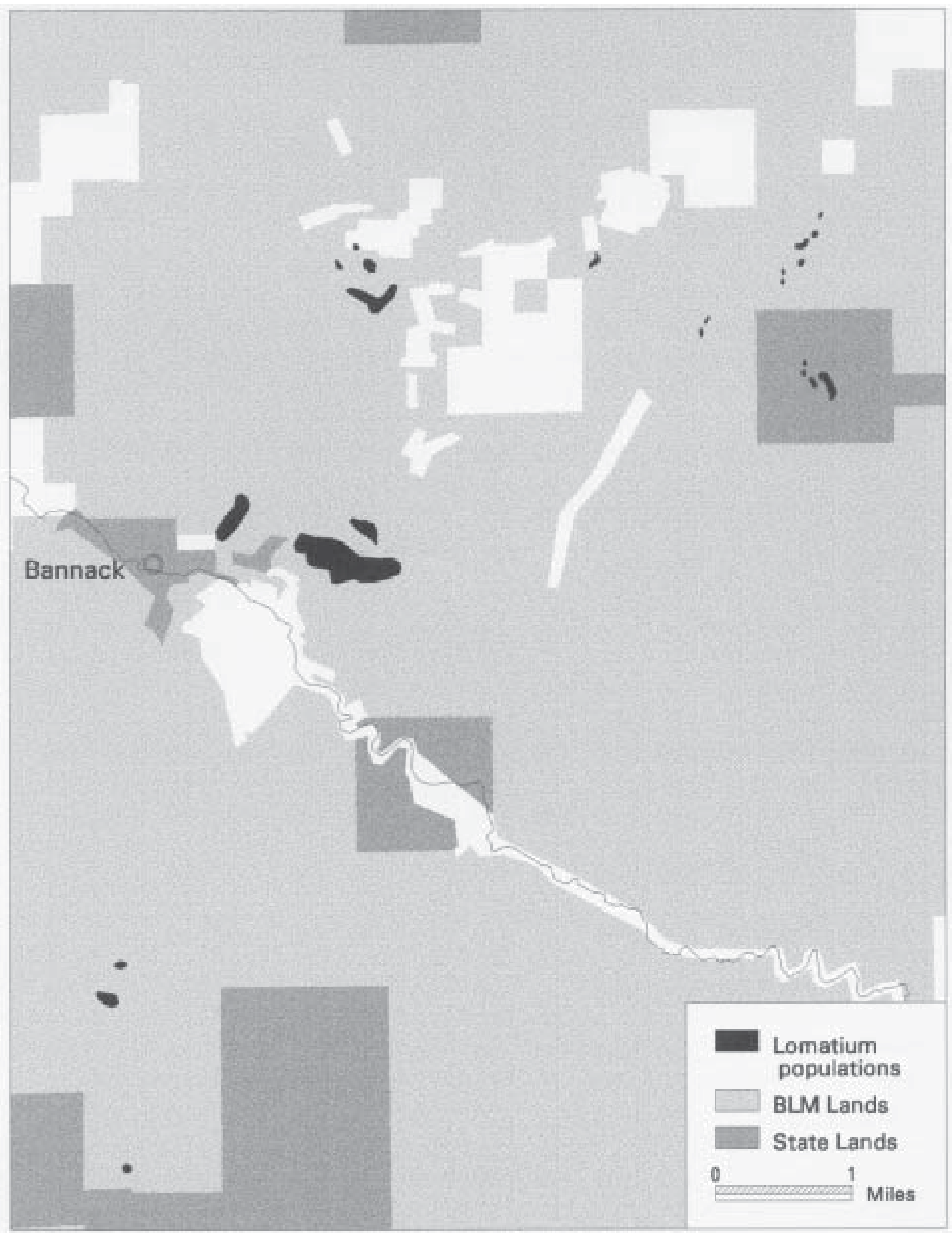

Montana Natural Heritage Program, February 04, 1998 
Soltis et al (1997) found lower levels of intrapopulational genetic variation (measured by isozyme electrophoresis) in three narrowly endemic species of Lomatium, than in three more widespread cogenenitors, although Lomatium attenuatum was not studied. Low genetic variability can be both a cause and result of rarity. The seeds of the Lomatium genus are flattened, an adaptation to dispersal by wind (Stebbins 1974).

\section{G. POPULATION ECOLOGY}

\section{BIOLOGICAL INTERACTIONS}

a. COMPETITION: Lomatium attenuatum usually grows in habitats with low plant cover where it experiences little competition from other species. It is a specialist adapted to a harsh environment that few other native species can exploit and in which its survival is not contingent on competitive ability. However, some introduced weeds are well adapted to open habitats with scree substrates. Spotted knapweed (Centaurea maculosa) in particular has infested vast areas of similar habitat in western Montana, but the species is not yet well established in southwestern Montana. Knapweed was observed near populations of Lomatium attenuatum in the Ruby and Tendoy ranges and its spread into population areas is probably the greatest potential threat to the species. The potential threat of other exotics such as annuals (Bromus tectorum, Malacomia africana) and nitrogen-fixers (Medicago lupulina, Melilotus officinalis) seems to be a secondary threat confined mainly to disturbance areas at present.

All occurrences are centered in settings with poorly-developed soils and exposed habitats that are unstable. The deeply-buried taproot and the tolerance of the rest of the plant to dessication afford it resilience in successional settings. Some plants showed signs of emerging from burial or having the surface layer swept away. It was locally common in a steep, southwestdraining ravine bottom made up of limestone cobbles (003), a local extreme in instability. It is not considered a pioneer species, but a waif individual was found on the streets of Bannack.

b. HERBIVORY: A few plant infloresences were browsed, but levels of herbivory were light. Lomatium attenuatum rarely grows in primary range, and much of its habitat is essentially inaccessible to cattle. Furthermore, its low stature diminishes the chances of grazing or browsing. Inflorescences are held above the leaves and were the only part observed browsed; herbivory is most likely to affect fruit production rather than plant survival. 


\section{ASSESSMENT AND MANAGEMENT RECOMMENDATIONS}

\section{A. THREATS TO CURRENTLY KNOWN POPULATIONS}

Current threats to Montana populations of Lomatium attenuatum are low. Greatest potential threats are invasion of habitat by introduced weeds and localized destruction of habitat by mining.

LIVESTOCK: Canyon bottom and canyon toeslope habitats of Lomatium attenuatum are the portions of its habitat with highest incidence of cattle grazing and trailing. They also have the highest levels of weed infestation. Exotic species present that demonstrate some ability to colonize scree slopes include black medic (Medicago lupulina) and common mullein (Verbascum thapsus). Neither is as aggressive as spotted knapweed (Centaurea maculosa), which was not seen in population areas but was seen in small numbers along travel routes into canyons in the Ruby (Laurin Canyon) and Tendoy (Limekiln Canyon) ranges. Elsewhere in western Montana, spotted knapweed has taken over large areas of limestone scree habitat. The species is just beginning to become established within the range of Lomatium attenuatum.

LOGGING: The canyon slopes harboring Lomatium attenuatum in the Ruby Range were logged before the turn of the century without apparent degradation of speciesí habitat. As mentioned previously, it often occurs in the more open or sparsely-vegetated of forested settings. Baring massive slope failures, the primary potential impact of contemporary logging practices would be in fostering exotic species invasion.

MINING: Past mining may have eliminated some habitat for the species, but no known occurrences are currently threatened by mining. Mining claims are located in the Ruby and Tendoy ranges, but active mines only occur near populations in the Grasshopper Creek drainage. These mines are centered along the contact zone between sedimentary (limestones) and igneous formations. Populations of Lomatium attenuatum occur on both rock types in this vicinity and it is likely that past mining (e.g. New Departure, DelMonte, and Iron Mask mines) has eliminated habitat of Lomatium attenuatum. Current levels of new threat are unknown, but existing mining activity potentially fosters noxious weed invasion.

ROADS: Parts of four occurrences (Deer Creek, Laurin Canyon, Limekiln Canyon, and Rocky Hills) are within areas closed off to motorized travel (U.S. Department of Agriculture et al. 1990). There is no new road construction apart from new developments. 
EXOTIC SPECIES: Exotic species pose a threat to Lomatium attenuatum in shifting the competition in favor of other species by nitrogen fixation (Medicago lupulina, Melilotus officinalis), providing direct competition for limiting resources like water (Centaurea maculosa, Verbascum thapsus), and degrading Lomatium attenuatum habitat with allelopathic agents (Centaurea maculosa).

\section{B. MANAGEMENT PRACTICES AND RESPONSE}

LIVESTOCK: In general, the rugged topography and lack of forage in habitats of Lomatium attenuatum minimize direct threats from livestock grazing. The species is not on primary range, and does not show signs of impact on secondary range. It might be affected by livestock grazing insofar as noxious weeds are treated or spread in the course of livestock management. It might also be affected by existing or proposed range management features in canyon bottoms and lower slopes (fences, salt blocks, impoundments) that lie within occurrences.

MINING: While mine sites were not surveyed for Lomatium attenuatum, it is to be assumed that the removal or burial of the occupied surface poses an impact. The Lomatium attenuatum is tolerant of surface instability, but the disturbance threshold around the zone of digging is not known. Spread of noxious weeds may be the most far-reaching threat of mining to this species.

ROADS: Habitat of Lomatium attenuatum is not suited for roadbed construction, but vehicles in road construction and subsequent traffic potentially spread noxious weeds, and roadbed corridors often become travel corridors for the establishment and spread of exotic species. Invasion of spotted knapweed may be the most serious threat to Lomatium attenuatum, and motorized vehicles are frequently its dispersal agents.

EXOTIC SPECIES: Noxious weed invasion is the most serious potential threat to the species, with the potential to occupy most or all of its habitat. Livestock, mining, and road construction potentially foster the spread of noxious weeds. Fortunately, the most serious noxious weed threats, including spotted knapweed, are only at early stages of invasion.

\section{RECOMMENDATIONS FOR MAINTAINING VIABLE POPULATIONS}

\section{MANAGEMENT RECOMMENDATIONS}

Treatment and eradication of spotted knapweed (Centaurea maculosa) is a priority for conservation of this species at Laurin Canyon and Limekiln Canyon. Periodic noxious weed surveys are recommended in the area of the nine occurrences, particularly along roads and at mining sites, and in the course of allotment plan updates. 
It is important to note that areas of additional potential habitat in the Ruby Range (Bouge and Robinson canyons), Tendoy Range (Kissick, Limekiln, McKenzie, and Rock canyons) and Grasshopper Creek drainage (Rocky Hills) that have not been surveyed. It is recommended that any prospective management planning activities in these areas include a survey for this and associated sensitive species.

The largest known population of Lomatium attenuatum is in the hills north of Bannack. This represents an area provisionally identified as a conservation priority, hosting four other plant species that are currently tracked as Montana Plant Species of Special Concern (Astragalus scaphoides, Lesquerella pulchella, Phacelia incana, Sphaeromeria argentea), three state or regional endemics that are on the state Watch list (Delphinium bicolor subsp. calcicola, Oryzopsis contracta, Townsendia spathulata), and other species that are no longer tracked (Arenaria kingii, Pediocactus simpsonii). The status of the R\&PP application for withdrawing this site from mining is unknown. An interim summary of site significance is presented in Vanderhorst (1995b), with continual occurrence and element updates in the Biological Conservation Database.

We do not recommend a formal monitoring but a general reassessment of its Montana status and BLM status within a ten-year period. Key points are identified in the following status recommendation section, and any new occurrence information should also be considered.

MTHP has implemented a data management convention that has management application. At some sites, it occurs intermittently across the broken topography, spanning as many as seven sections in a single occurrence (EO\#001). The patchy distribution boundaries of these element occurrences have been digitized for accurate information retrieval in the Biological Conservation Database (BCD), particularly critical in conducting reviews of proposed projects that are confined to small areas.

\section{STATUS RECOMMENDATIONS}

Current BLM status of Lomatium attenuatum is recommended changed from Sensitive to Watch status because there are several extensive populations with relatively broad ecological amplitude, high numbers, and low degree of threats in three separate areas. Sensitive status should be reconsidered if:

1) Population declines become evident,

2) Infestation of weeds, especially spotted knapweed, are documented in population areas, or

3) Mining is proposed in major population areas. 
Current global rank (G2) assigned by The Nature Conservancy warrants reconsideration. Definition of G2 status is iimperiled because of rarity (6 to 20 occurrences), or because of other factors making it very vulnerable throughout its rangeî (Heidel 1997). There are now a total of 22 occurrences documented in Montana and Wyoming (Montana Natural Heritage Program and Wyoming Natural Diversity Database records). The same factors supporting BLM status change in Montana lend further support to the case for rangewide rank change to G3 (globally vulnerabletypically 20-100 occurrences). These include the several extensive populations with fairly broad ecological amplitude, high numbers, and low degree of threats in a four separate areas rangewide. Current Montana state rank (S2) remains appropriate.

\section{INFORMATION SOURCES}

A. HERBARIUM SPECIMENS: Specimen vouchers were deposited at two herbaria:

Montana State University (MONT)-J. Vanderhorst 5191, 5222, 5436, 5441, 5645, 5642, 5645, 5651, 5652, 5654, 5658, 5661, University of Montana (MONTU)-P. Lesica 5990, 6078, 6081, 6127, 6294; B. Heidel 1477,1561

Note: Specimen vouchers are cited on the individual element occurrences (Appendix A).

B. FIELDWORK: Field surveys were conducted over a two week period in early June of 1997 by Jim Vanderhorst.

\section{LITERATURE CITED}

Buchmann, S. L. and G. P. Nabhan. 1996. The Forgotten Pollinators. Island Press, Washington, D.C. $292 \mathrm{pp}$.

Constance, L. 1993. Apiaceae. in The Jepson manual. ed. J. C. Hickman. University of California Press, Berkely, CA.

Culver, D. R. 1993. Sensitive plant species inventory in the Centennial Valley, Beaverhead County. Unpublished report to the Bureau of Land Management. Montana Natural Heritage Program, Helena. 42 pp. + app.

Dorn, R. D. 1989. A report on the status of Lomatium attenuatum, a Candidate Threatened Species. Unpublished report for the U.S. Fish and Wildlife Service. Mountain West Environmental Services, Cheyenne, WY. 
Dorn, R. D. 1992. Vascular Plants of Wyoming, $2^{\text {nd }}$ ed. Mountain West Publishing. Cheyenne, WY. $340 \mathrm{pp}$.

Evert, E. F. 1983. A new species of Lomatium (Umbelliferae) from Wyoming. MadroÒo 30(3): 143146.

Fertig, W. 1996. Wyoming Plant Species of Special Concern. Wyoming Natural Diversity Database. $32 \mathrm{pp}$.

Fertig, W. 1997. Plant species of special concern on Shoshone National Forest: 1996 results. Unpublished report to Shoshone National Forest. Wyoming Natural Diversity Database, Laramie, WY.

Heidel, B. L. 1997. Montana Plant Species of Special Concern. Montana Natural Heritage Inventory. 34 pp.

Heidel, B. L. and J. Vanderhorst. 1996. Sensitive plant surveys in Beaverhead and Madison counties, MT. Unpublished report to Bureau of Land Management. Montana Natural Heritage Program, Helena. 85 pp. + app.

Marriott, H. 1989. Status of Lomatium attenuatum. p. 15, In: Rare, sensitive, and threatened species of the Greater Yellowstone Ecosystem, T. W. Clark, A. H Harvey, R. D. Dorn, D. L. Genter, and C. Groves, eds. Northern Rockies Conservation Cooperative, Montana Natural Heritage Program, The Nature Conservancy, and Mountain West Environmental Services. 153 pp.

Soltis, P. S., D. E. Soltis, and T. L. Norvell. 1997. Genetic diversity in rare and widespread species of Lomatium (Apiaceae). MadroÒo 44: 59-73.

Stebbins, G. L. 1974. Flowering Plants ñ Evolution above the Species Level. Belknap Press of Harvard University Press, Cambridge, MA. 399 pp.

U. S. Department of Agriculture, U.S. Department of Interior, and State of Montana. 1990. Interagency visitor map, Southwest Montana.

U. S. Department of Commerce, National Oceanic and Atmospheric Administration. 1982. Monthly normals of temperature, precipitation, and heating and cooling degree days, 1951-1980, Montana. Climatography of the United States no. 81. National Climatic Center, Ashville, NC.

U. S. Department of the Interior, Bureau of Land Management. 1996. Special status species management; Supplement 6840 of 8 April 1996. Billings, MT. 
U. S. Department of the Interior, Fish and Wildlife Service. 1993. Plant taxa for listing as endangered or threatened species; notice of review. Federal Register 58 (188): 51144-51190.

. 1996. Endangered and threatened

wildlife and plants; Notice of final decision on identification of candidates for listing as endangered or threatened. Federal Register 61(235): 64481-64485.

Vanderhorst, J. 1994a. Survey for sensitive plants on Dutchman Mountain, Beaverhead County, Montana. Unpublished report to the Bureau of Land Management. Montana Natural Heritage Program, Helena. 5 pp. + app.

. 1994b. Survey for sensitive plant species in the vicinity of Lemhi Pass, Beaverhead County, Montana. Unpublished report to the Bureau of Land Management. Montana Natural Heritage Program, Helena. 5 pp. + app.

. 1995a. Sensitive plant survey of the Tendoy Mountains in the Beaverhead National Forest, Beaverhead County, Montana. Unpublished report to Beaverhead National Forest. Montana Natural Heritage Program, Helena. 68 pp.

. 1995b. Survey of Bannack State Park and vicinity for Montana plant species of special concern. Unpublished report to Bannack State Park, Montana Department of Fish, Wildlife, and Parks, Dillon, MT. Montana Natural Heritage Program, Helena. 23 pp + app. . 1995c. Sensitive plant survey in the Horse Prairie Creek drainage, Beaverhead County, Montana. Unpublished report to the Bureau of Land Management. Montana Natural Heritage Program, Helena. 42 pp. + app.

Vanderhorst, J. and B. L. Heidel. 1995. Sensitive plant survey in the Tobacco Root Mountains, Madison County, MT. Montana Natural Heritage Program, Helena.

Vanderhorst, J., B. L. Heidel, J. Pierce, and S. V. Cooper. 1997. Botanical survey of the Ruby Range, Madison County, Montana. Unpublished report to Bureau of Land Management. Montana Natural Heritage Program, Helena.

Vanderhorst, J. and P. Lesica. 1994. Sensitive plant survey in the Tendoy Mountains, Beaverhead County, MT. Unpublished report to Bureau of Land Management. Montana Natural Heritage Program, Helena. $60 \mathrm{pp}+$ app. 